\title{
Article
}

\section{Does organizational creativity always drive market performance?}

Boso, Nathaniel, Donbesuur, Francis, Bendega, Terver, Annan, Jonathan and Adeola, Ogechi

Available at http://clok.uclan.ac.uk/28571/

Boso, Nathaniel, Donbesuur, Francis ORCID: 0000-0003-3793-802X, Bendega, Terver, Annan, Jonathan and Adeola, Ogechi (2017) Does organizational creativity always drive market performance? Psychology and Marketing, 34 (11). pp. 1004-1015. ISSN 0742-6046

It is advisable to refer to the publisher's version if you intend to cite from the work. http://dx.doi.org/10.1002/mar.21039

For more information about UCLan's research in this area go to http://www.uclan.ac.uk/researchgroups/ and search for <name of research Group>.

For information about Research generally at UCLan please go to http://www.uclan.ac.uk/research/

All outputs in CLoK are protected by Intellectual Property Rights law, including Copyright law. Copyright, IPR and Moral Rights for the works on this site are retained by the individual authors and/or other copyright owners. Terms and conditions for use of this material are defined in the policies page.

\section{CLoK}

Central Lancashire online Knowledge www.clok.uclan.ac.uk

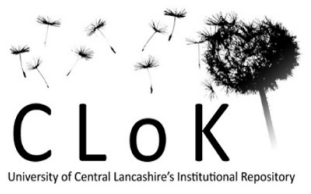




\title{
DOES ORGANIZATIONAL CREATIVITY ALWAYS DRIVE MARKET PERFORMANCE?
}

\author{
Nathaniel Boso ${ }^{1}$ \\ Leeds University Business School \\ University of Leeds \\ LS2 7JT, United Kingdom \\ Tel: +441133432636 \\ Email: n.boso@leeds.ac.uk \\ Francis Donbesuur \\ Leeds University Business School \\ University of Leeds \\ LS2 7JT, United Kingdom \\ Tel: +447480210878 \\ Email: bnfd@leeds.ac.uk \\ Terver Bendega \\ Taxify Nigeria \\ Lagos \\ Email: terverbendega@yahoo.com
}

Jonathan Annan

Kwame Nkrumah University of Science and Technology

KNUST School of Business

Kumasi, Ghana

Tel: +233202508605

Email: jothananan@yahoo.com

Ogechi Adeola

Lagos Business School

Pan-Atlantic University

Km 52 Lekki-Epe Expressway, Nigeria

Tel: +2348025017873

Email: oadeola@1bs.edu.ng

${ }^{1}$ Corresponding Author 


\begin{abstract}
This study develops and tests arguments that the relationship between organizational creativity and market performance is channelled through new product development (NPD) capability, and that the indirect effect of creativity on performance, via NPD capability, is conditional upon levels of environment dynamism and market responsiveness. The proposed relationships are tested on a sample of 221 small and medium sized enterprises (SMEs) in a major sub-Saharan African market. Findings from the study indicate that process and product NPD capabilities partially mediate the effect of novelty and usefulness elements of organizational creativity on market performance. The study further finds that while environment dynamism weakens the indirect effects of novelty and usefulness of organizational creativity, via process and product NPD capabilities, on market performance, the effects are strengthened under conditions of greater responsiveness to target market needs. A theoretical contribution from this study is the finding that how organizational creativity dimensions drive market performance is more complex than previously thought: it depends on whether or not organizational creativity components are first used to develop an organization's process and product innovation capabilities, and whether target market environment conditions are dynamic and an organization has ability to respond to target market demands.
\end{abstract}

KEYWORDS: organizational creativity; NPD capability; environment dynamism; responsiveness; market performance; developing economy 


\section{INTRODUCTION}

The increasing complexity of global business activity characterized by unpredictability and turbulence has driven many scholarly works (e.g., Anderson, Potočnik \& Zhou, 2014; Damanpour \& Aravind, 2012; Sarooghi, Libaersa, \& Burkemper, 2015) and organizational leaders to recognize the importance of organizational creativity for growth and survival. A study of 1,500 CEOs across 60 countries and 33 industries shows that greater organizational creativity is the vital determinant of sustainable market performance (International Business Machines, 2010). It is, therefore, not surprising that there have been sustained scholarly and practitioner interests in explaining how creativity drives organizational success. Despite scholarly and practitioner interests, the academic literature on organizational creativity remains remarkably inconsistent and often inconclusive in explaining the processes through which organizational creativity influences market performance (Hennessey \& Amabile, 2010; Montag, Maertz, \& Baer, 2012).

Additionally, the creativity literature has long suggested that the organizational creativityperformance relationship may be conditional upon the context within which creativity is exhibited (Sarooghi, Libaersa, \& Burkemper, 2015; Zaltman, Duncan, \& Holbek, 1973). For example, Sarooghi, Libaersa and Burkemper (2015) have argued that the effect of creativity on innovation performance is highly context dependent, and call on researchers to account for relevant boundary conditions when examining this important relationship. However, theoretical specification of the relationship between organizational creativity and market performance continue to lack vigorous examination of relevant contingencies that may moderate this vital relationship. Empirically, previous research on organizational creativity has been dominated by data from industrialized Western European and North American markets. Evidence from less-developed markets remains limited in this research stream. Yet, the creativity literature suggest that creativity is often exhibited under conditions of severe resource shortage (Troilo, De Luca, \& Atuahene- Gima, 2014; Zeschky, Winterhalter, \& Gassmann, 2014), highlighting the adage that "necessity is the mother of invention" (Gibbert, Hoegl, \& Valikangas, 2013, p. 197). An important implication of these gaps in the organizational creativity literature is that 
knowledge is lacking on how and when this relationship works in less-developed societies (Weinzimmer, Michel, \& Franczak, 2011). Thus, this study proceeds on the premise that new product development (NPD) capability plays an intervening role in the organizational creativity-market performance relationship, and that the indirect causal link from organizational creativity to market performance, via NPD capability, is conditional upon levels of environment dynamism and degrees of responsiveness to market needs in a developing-economy market setting.

The study integrates the resource-based theory and organizational ecology principles to explain the proposed mechanisms and boundary conditions. The resource-based theory provides the basis for identifying organizational creativity as an idiosyncratic organizational resource and NPD capability as an organizational competence, while the merit for the use of environmental dynamism and market responsiveness as contingencies is predicated on organizational ecology principles. This study argues that a theoretical specification and an empirical assessment of the proposed relationships help shed new insights on the scholarly and managerial understanding of how and when organizational creativity boosts firm performance. First, the study contributes to the organizational creativity literature by broadening existing knowledge on the path from organizational creativity to market performance. Second, by modelling creativity as an idiosyncratic firm-specific resource that enables a firm to create NPD capabilities, and environment dynamism and market responsiveness as contingencies of the effects of NPD capabilities on performance, this study offers new managerial insights into how to enhance performance benefits of organizational creativity. Third, in bringing on board a developing-economy market perspective to the study of organizational creativity, this study helps broaden the scope of empirical analysis of organizational creativity and its economic values, which has by far been limited to industrialized market perspectives.

The remainder of this paper is organized as follows. First, the paper elaborates on the existing organizational creativity literature, focusing on explaining its relationship with market performance outcome, while evaluating how new product development (NPD) capabilities serve as channel to connect creativity to performance. Second, a series of propositions are put forward to explain how the 
indirect effect of creativity on performance, via NPD capabilities, is dependent upon levels of environment dynamism and market response capability (see figure 1). Third, empirical approaches followed and results of empirical studies are presented. Finally, the study discusses how findings from this study help advance existing knowledge on organizational creativity and areas where future research can improve upon findings presented in this research.

\section{[Insert Figure 1 here]}

\section{THEORETICAL BACKGROUND AND HYPOTHESES}

\subsection{Organizational creativity and its consequences}

The creativity construct has received significant scholarly attention in the fields of organizational psychology (Glăveanu, 2014; Gong, Zhou, \& Chang, 2013; Csikszentmihalyi \& Sawyer, 2014), organizational behavior (Amabile, 1988; Litchfield, Ford, \& Gentry, 2015), marketing (Agnihotri, Rapp, Andzulis, \& Gabler, 2014; Sethi, Smith, \& Park 2001) and economics (e.g., Audretsch \& Belitski, 2013; McMullan \& Kenworthy, 2015). The goal is to understand why certain individuals, groups or organizations are more likely (than others) to channel creativity to solve personal, organizational and societal problems. Despite the growing scholarly interests, there is lack of consensus regarding the definition of creativity. However, a widely used definition is that creativity entails "production of novel and useful ideas in any domain" (Amabile, 1988, p.1155), which are meaningful (Oldham \& Cummings, 1996).

Within the field of marketing, creativity is often conceptualized at the organizational level to explain the extent to which firms offer unique and valuable solutions to market problems (Agnihotri, Rapp, Andzulis, \& Gabler, 2014; Sethi et al., 2001; Sok \& O'Cass, 2015). For example, Agnihotri, Rapp, Andzulis, and Gabler (2014) develop a model to argue that creative boundary spanners enable an organization to improve its service offerings to boost its performance. Against this background, "novelty" and "usefulness" have been argued in the marketing literature to be vital defining elements of organizational creativity (Paletz \& Peng, 2008). Thus, this study follows Sethi et al. (2001) to define 
organizational creativity as the degree to which new products or services offered by a firm differ from existing alternatives in ways that are both novel and useful to customers.

Although several scholarly works have examined the link between organizational creativity and performance, empirical evidence has so far been largely inconclusive and conflicting (see Sethi et al., 2001; Im \& Workman, 2004; Eryigit \& Uslu, 20016). A contention is that although individual-level behavioral trait of creativity may boost overall performance, creativity from a strategic management standpoint is argued as a vital determinant of organizational-level performance. From this organizational level perspective, creativity is viewed as an organizational culture-based resource that legitimizes creative behavior among organizational members to improve organizational performance (Weinzimmer, Michel, \& Franczak, 2011). However, Bilgliardi (2013) finds a weak empirical evidence for the suggested effect of organizational creativity on performance. Given these conflicting evidence, Nordenflycht (2007) argues that it is important to examine the mechanisms through which creativity influences performance. In following Nordenflycht's call, Weinzimmer, Michel and Franczak (2011) examine the effect of organizational creativity on performance via action orientation, arguing that superior organizational performance is achieved through strategy implementation effectiveness. Weinzimmer and colleagues (p. 62) conclude that it is a "firm's ability to actually enact creativity that impacts firm-level performance".

In their guidance for improving scholarly research on the creativity-performance relationship, Weinzimmer and colleagues propose that researchers may follow Christensen's $(2000 ; 2013)$ resourceprocess-value framework to conceptualize organizational creativity as an organizational resource that drives internal organizational processes and routines to create economic value for organizations. In drawing insights from resource-based theory and by using Christensen's analytical framework, therefore, this study conceptualizes organizational creativity as an organizational culture-based resource that drives market performance via NPD capability processes. This study posits that organizational creativity provides a firm with a differentiation advantage to earn superior market performance (Hunt \& Morgan, 1996) by triggering a process of "selling ideas, mobilizing sponsorship, gathering the 
necessary resources, creating the innovation, and introducing the innovation to the marketplace" (Sarooghi, Libaers, \& Burkemper, 2015, p. 2). Thus, the literature suggests that development of new processes and products is driven by a propensity to come up with a novel and useful ideas (Axtell, Holman, Unsworth, Wall, Waterson, \& Harrington, 2000).

Organizational creativity exhibited in the generation of novel and useful solutions to marketplace problems provides a strong ground for a firm to develop new processes and products for its target market (Somech \& Drach-Zahavy, 2013). A firm with a superior capability to introduce new processes and products is more likely to distinguish its market offerings from the competition and occupy a lucrative market position that is too costly for competitors to replicate (Song \& Parry, 1997; Hogan, \& Coote, 2014; Rousseau, Mathias, Madden, \& Crook, 2016). Along this line, Zhao \& Chadwick (2013) contend that while an average organization can attain occasional success in introducing new processes and products to the market, a firm with a superior NPD capability is better positioned to sustain market successes. Market successes are likely to accrue to a creative firm because first-mover advantages obtained from novelty and usefulness market solutions help such a firm to erect entry barriers against competitors and deny market rivals opportunity to earn customer loyalty (Wernerfelt, 1984; Barney, 1991). Therefore, this study contends that organizational creativity translates into market performance when channelled through NPD capabilities. In short, if a firm is creative, it should be more effective in developing and commercializing new processes and products that are valuable, rare, imperfectly imitable and non-substitutable. Increased success in new process and product introductions heightens the chances that the firm would record superior market performance. Accordingly, this study hypothesizes:

$H_{1}$ : Organizational creativity has an indirect, positive relationship, via NPD capabilities, with market performance. 


\subsection{Moderating role of environment dynamism}

The organizational ecology literature suggests that variability in a firm's market environment has important implications for effective deployment of organizational resources and capabilities (Narver, Slater, \& MacLachlan, 2004). In drawing on the organizational ecology literature, Joshi and Campbell (2003) suggest that a firm's external market environment conditions can facilitate or dampen the success outcomes of organizational capabilities. A more recent study by Chan, Yee, Dai and Lim (2016) finds that the effect of green product innovation on performance is contingent upon degree of environment dynamism. In a qualitative interview with a senior product manager of an alcoholic beverage company in a large sub-Saharan African market - Nigeria, it emerged that, "The Nigerian environment is unique in its own right. It's a market that is difficult to predict which is why data is always very crucial. Local consumers are very unique: they are very price sensitive yet extremely averse to products that are perceived to be 'cheap.' At the same time, the way competition operates is different. Competition here takes the form of fake products and rival firms introducing brands whose sole aim is to undercut other brands and force competitors into a price war...it is important to anticipate and have contingency plans because there is so much uncertainty. Even now the exchange rate fluctuation is heavily impacting on business. So this business focused on introducing new products in one state to gauge demand and then set key performance indicators (KPIs) in terms of number of volume, salience, awareness, and top of mind. In less than four months the company saw that six month KP1s were surpassed. It is at that point that the company knew it was a winner." The evidence presented above implies that changes in the external environment present challenges and opportunities for firms, especially those operating in turbulent market environment such as sub-Saharan Africa. Dynamism in the external environment depicts the unpredictability of competitive strategies and offerings, changes in consumer tastes and preferences, and variations in regulatory forces (Joshi \& Campbell, 203).

This study contends that NPD capabilities of new processes and products are most likely to be beneficial to firms when they are deployed in an environment of greater dynamism where key market indicators (e.g. customer needs, competitive strategies and regulatory forces) are in constant flux. Such 
continuous and unpredictable changes suggest that success is likely to be determined by a firm's ability to develop and commercialize new processes and products that meet or exceeds consumer expectations. This need for greater NPD capabilities in dynamic market environments for stronger performance enables this study to argue that:

$\mathrm{H}_{2}$. Environmental dynamism moderates the positive indirect effect of organizational creativity on market performance, via NPD capabilities, such that at high levels of environment dynamism, the effects of NPD capabilities on market performance are accentuated.

\subsection{The Moderating role of market responsiveness}

This study further argues that the extent to which organizational creativity drives performance, via NPD capabilities, is dependent upon a firm's ability to respond to local target market needs and demands. A product manager of an alcoholic beverage company in Nigeria remarked that, "Understanding the market is important to how this firm operates. This company initially discovered that consumers wanted a totally new proposition beyond beer, larger or stout. A trend noticed on the market was that consumers wanted something that would connect them to their roots in terms of African herbs. That was a whole new category that was being dominated by unbranded 'bitters' products. So after conducting extensive research the company determined that it had clear advantages in terms of spending power, premium brand reputation and established infrastructure on the market, especially in terms of sales and distribution networks on the market." In addition to the above quote a qualitative interview conduct for this study, Wei, Samiee and Lee (2014) provide evidence from emerging market firms to show that firms that possess high levels of innovation capability and strong market responsiveness are able to elevate their leadership positions in particular target markets. Such firms exhibit capability to "regularly refine their offers, develop new ones in response to the prevailing market conditions, and remain adaptive, forward-moving, and willing to change” (Wei, Samiee and Lee, 2014, p. 49).

The above evidence indicates that the extent to which NPD capabilities drive market performance is dependent upon a firm's ability to respond to local market needs. This contention could 
be based on the organizational ecology literature that seeks to explain why some businesses grow and succeed, while others decline and fail in particular environment (George, 2002). It is argued that some firms succeed because they have ability to adjust their market offerings to target local market needs (Hannan \& Freeman, 1993; sheth, 2011). By this reasoning and with the evidence provided from the qualitative studies, this study proposes that firms that are responsive to local market needs and demands are more likely to be successful in introducing commercially viable new processes and products than firms that are rigid and resistant to change. Similarly, because locally-responsive firms invest in market sensing and monitoring activities (Bharadwaj \& Dong, 2014; Narver, Slater, \& MacLachlan, 2004), they are better prepared than less responsive counterparts to explore, develop and commercialize new products that do well on the market. On the contrary, firms that ignore trends on the market and are slow in responding to changing market needs face the prospect of not being able to innovate to make those changing market needs (Ofek and Wathieu, 2010). Accordingly, the study hypothesizes that:

$H_{3}$. Market responsiveness capability moderates the positive indirect effect of organizational creativity on market performance, via NPD capabilities, such that at high levels of market responsiveness capability, the effect of NPD capabilities on market performance are strengthened.

\section{RESEARCH DESIGN}

\subsection{Sampling and data collection}

To test the study's conceptual model in Figure 1, primary data was obtained from small and mediumsized enterprises (SMEs) in Nigeria, a sub-Saharan African market. Two reasons informed the choice of Nigeria. First, Nigeria is the largest economy in sub-Saharan Africa with approximately 182.2 million people (Trading Economies, 2015) and an estimated GDP of USD1.105 Trillion (and 6.3\% annual growth rate). Second, Nigeria operates an open market economy, which has led to an increased presence of privately owned small businesses in that country. With this socio-economic background, Nigeria provides economic, social and environmental context to examine how Western marketing theories which are assumed to be 'universal' operate in a large sub-Sahara African economy. 
The study relied on an in-depth case study to gain a deeper understanding of patterns, processes and meanings that underpinned how organizational creativity activities shaped a firm's market success. Insights from the case study then informed collection of survey and archival data to statistically examine how NPD capability intervenes in the processes that connect organizational creativity to market performance. The sampling frame was taken from a directory of SMEs provided by Nigeria's Small Business Bureau. To supplement this list, an additional list from Nigerian Business Directory was used. Both directories provided names, addresses, and telephone numbers of senior company executives including lead entrepreneurs (or chief executive officers). The firms on the databases were screened to ensure that the following study criteria are met: (1) that the firms are independent entities and were not part of any company group or chain; (2) that the companies are owned and controlled by private individuals with majority ownership; (3) that the firms have been operating in this sub-Sahara African country for at least 5 years; (4) that the firms employ between 5 and 249 full-time staff; and (5) that there are complete contact information on senior managers and finance directors or chief accountants to ensure multiple sources of information on the variables studied. Having contacted and obtained cooperation from the firms, a total of 450 firms were interviewed over a period of three years: novelty and usefulness of organizational creativity in time 1 (i.e., 2014), NPD capabilities, environment dynamism and market responsiveness in time 2 (i.e., 2015) and market performance in time 3 (i.e., 2016). While CEOs, product and R\&D managers were interviewed for information on the creativity, NPD and moderator variables, finance directors (and accountants in few cases) were interviewed for information on the firm's market performance data. In the end, 221 matched valid responses were received, yielding a response rate of about $49 \%$.

\subsection{Measures}

The items used to measure the constructs were generated from the existing literature, and where necessary, wordings of items were adjusted to aid respondents' understanding. Respondents were asked to rate the extent to which each item accurately described their organizations' activities on a seven-point 
Likert scale. Table 1 provides details of measures used for each construct, their sources and their respective reliability and validity tests. Organizational creativity (novelty and usefulness) measures were adapted from Sue-Chan and Hempel (2016), while NPD capabilities items were adapted from Atuahene-Gima and Li (2004) and Calantone, Cavusgil and Zhao (2002). Measures of environment dynamism and market responsiveness were adapted from Jaworski and Kohli (1993). Market performance items were taken from Sirén, Kohtamäki and Kuckertz (2012). Consistent with previous empirical studies, this study controlled for three industry and organizational related variables due to their potential effects on firm performance: industry dummy (manufacturing $=0$ and service $=1$ ), business experience (total number of years in business) and firm size (total number of full-time employees) (Woodman et al., 1993).

\subsection{Reliability and Validity Assessment}

Confirmatory factor analysis (CFA) was undertaken to establish the psychometric properties of the measures used. Validity of the measures was assessed using the Cronbach's Alpha score, composite reliability (CR), and average variance extracted (AVE). Encouraging results were obtained with all measures in the study exceeding their recommended thresholds. Specifically, the dimensions of creativity (novelty and usefulness) had reliability scores of .90 and .86 respectively while the dimensions of NPD (process and product) had scores of .92 and .88 respectively. The smallest reliability value was .79 for responsiveness which is still larger than the recommended .70 indicating a high validity of the construct. As can be seen in Table 1, CR and AVE for each scale were acceptable, respectively exceeding the minimum threshold of .60 and .50 . Without exception, all items loaded on their hypothesized latent constructs with no evidence of cross-loading. Table 2 provides details of the descriptive statistics and correlation among the key constructs studied.

\section{[Insert Table 1 and Table 2 here]}

\section{ANALYSIS AND RESULTS}


The study's hypotheses were tested using structural equation modelling technique. This approach is preferred as it allows for control variables, main effects and interaction effects to be tested hierarchically and simultaneously while taking into account measurement error. The maximum likelihood estimator and covariance matrix were used as input variables, and implemented in LISREL 8.71. Consistent with established practices (Ping, 1995), model complexity was decreased by computing averages for each multi-item construct to generate single indicants. The constructs used for multiplicative interactive analysis were mean-centered before their product-terms were computed, helping control for any multicollinearity problem (Aiken, West, \& Reno, 1991). Subsequently, the moderator variables (i.e. dynamism and responsiveness) were multiplied by the two components of NPD capability (i.e. NPD process and NPD product) to create four product-terms: NPD process $\mathrm{x}$ dynamism; NPD product $\mathrm{x}$ dynamism; NPD process x market responsiveness; and NPD product x market responsiveness.

The study argues in Hypothesis 1 that organizational creativity has a positive indirect effect on market performance via NPD capabilities. As shown in Table 3, usefulness and novelty components of organizational creativity are both positively and significantly related to new process and new product development capabilities (usefulness: $\gamma=.289 ; \mathrm{t}=4.774 ; \mathrm{p}<0.01 ;$ novelty: $\gamma=.627 ; \mathrm{t}=10.254 ; \mathrm{p}<$ 0.01). Similarly, both the process $(\gamma=.216 ; \mathrm{t}=3.242 ; \mathrm{p}<0.01)$ and product $(\gamma=.115 ; \mathrm{t}=2.063 ; \mathrm{p}<$ 0.05) components of NPD capability are positively and significantly related to market performance. Usefulness and novelty are not directly related to market performance. This suggests, therefore, that the causal chain from organizational creativity to market performance is through NPD capabilities. Given that usefulness and novelty components of creativity are both not directly related to market performance, the study concludes that process and product NPD capabilities fully mediate the effect of novelty and usefulness organizational creativity on market performance.

The study argues in hypotheses 2 and 3 that the indirect effect of organizational creativity on market performance, via NPD capabilities, is conditional upon levels of environment dynamism and market responsiveness. To estimate these paths, three nested models were estimated and compared hierarchically. In Model 1, the control paths were estimated on market performance (excluding the 
direct effects of usefulness and novelty). In Model 2, the indirect main effect paths were estimated: novelty and usefulness $\rightarrow$ NPD product and NPD process $\rightarrow$ market performance (with the four interaction terms forced to take on the value of zero). In Model 3, the control paths, the indirect main effect paths as well as the four interaction terms were freely estimated. Chi-square difference test was then used to determine the extent to which these three models fit the data. Results show that Model 3 significantly fit the data better than Model 1 and Model 2; hence Model 3 was relied upon for interpretation of the study results. Contrary to expectation, greater levels of environment dynamism weaken the effect of NPD process capability $(\gamma=-.188 ; \mathrm{t}=-2.242 ; \mathrm{p}<0.05)$ and NPD product capability $(\gamma=-.203 ; \mathrm{t}=-3.221 ; \mathrm{p}<0.01)$ on market performance. However, consistent with the study's prediction, results show that the effects of NPD process capability $(\gamma=.142 ; \mathrm{t}=1.681 ; \mathrm{p}<0.10)$ and NPD product capability $(\gamma=.192 ; \mathrm{t}=1.962 ; \mathrm{p}<0.05)$ on performance are strengthened when market responsiveness levels are high.

\section{[Insert Table 3 here]}

\section{ADDITIONAL ANALYSES}

To explore the findings further and to establish robustness of findings from the study, two additional analyses were undertaken. First, Dawson's (2011) and Aiken, West and Reno's (1991) recommendations were followed to further explore the interaction effect relationships at different levels of the two moderators. Specifically, the relationships were further tested in a series of mediationmoderation analyses using the PROCESS macro (Hayes, 2013) with 5000 bootstrap and bias-corrected 95\% confidence intervals (CI). The PROCESS approach is able to estimate the conditional direct and indirect effects of novelty and usefulness creativity on market performance, via process and product NPD capability, at \pm 1 standard deviation of the mean values of environment dynamism and market responsiveness. In Figure $2 \mathrm{a}-\mathrm{b}$, the effects of process and product NPD capabilities on market performance are stronger when environment dynamism takes on lower values below the mean. However, findings presented in Figure 3a-b show that when market responsiveness takes on larger 
values above the mean, the effects of process and product NPD capabilities on market performance are stronger. These findings reiterate the conclusion reached in this study that the indirect effects of novelty and usefulness organizational creativity resources on market performance, via process and product NPD capabilities, are strengthened when levels of the two NPD capabilities are high and when degrees of environment turbulence are low and market responsiveness levels are high.

\section{[Figures 2a-b and Figures 3a-b here]}

Second, some studies have argued that converting creative into innovative ideas is a complex process due to the fact that creativity and NPD activities might not proceed in a linear function (Sarooghi et al., 2015), highlighting an earlier contention that organizational creativity might not always drive innovation capability (Çokpekin \& Knusden, 2012), and market performance. To rule out these contentions, the study estimated quadratic effect relationships between novelty and usefulness organizational creativities and process and product NPD capabilities, and between the organizational creativities and market performance. This was done by squaring the mean-centered values of novelty and usefulness organizational creativity components. Findings show that the novelty and usefulness quadratic terms are neither significantly related to the two NPD capabilities nor market performance.

\section{DISCUSSIONS AND IMPLICATIONS}

The purpose of this study is to explain the intervening role of NPD capabilities in the organizational creativity-market performance relationship and the environment dynamism and market responsiveness conditions under which creativity drives performance via NPD capabilities. Theoretical and managerial implications of the findings are presented next.

\subsection{Theoretical Implications}

The established creativity literature argues in favor of a beneficial organizational -performance relationship. However, empirical evidence remains conflicting and inconclusive (i.e. Sethi et al., 2001; 
Wang \& Miao, 2015). A major contribution from this study is its ability to account for the mechanisms and conditions under which organizational creativity resources impact market performance. Results of this study build on extant literature on creativity by providing evidence to show that the creativity performance relationship is mediated by new product development capabilities. In short, this study's findings indicate that organizations that sustainably develop and commercialize new processes and products are more likely to record superior market performance than rival firms. This is because NPD capabilities enables businesses to remain competitive in the face of market pressure.

The study further contributes to existing literature by showing the boundary conditions that shape the effect of NPD capabilities on market performance. Although the path from NPD capability to performance has been argued in previous research to be positive (e.g., Hogan \& Coote, 2014; Rousseau, Mathias, Madden, \& Crook, 2016) the literature also presents systematic evidence that the relationship is, in fact, more complex. For example, Im's (1999) research finds that market potential and competitive intensity moderates the NPD capability - performance relationship. Similarly, Story, Boso and Cadogan's (2015) study argue the relationship between firm innovation and performance is curvilinear, and that the relationship is further conditioned by market orientation and access to financial resources.

Contrary to this study's expectation and in a departure from established literature on organizational innovation, results indicate that, at least in Nigeria, the relationship between NPD capabilities and market performance is weakened at increasing levels of environment dynamism. There are two plausible explanations for this counterintuitive finding. First, this unexpected finding may draw organizational creativity and innovation scholar's attention to the notion of consumer confusion (Woodward \& Hall, 2012), a concept that is widely studied in consumer psychology but rarely explored in organizational creativity and innovation research. This study argues that growing competition among market players to introduce new processes and products may cause consumers to be confused about the unique value that new processes and products provide over and above competing and existing processes and products. Increased consumer exposure to new processes and products increases information overload, subsequently creating conscious/unconscious confusion among consumers (Walsh et al., 
2016; Ermeç \& Kavak, 2017). This consumer confusion may also be related to ambiguity in new product information and product similarity (Mitchell and Papavassilious, 1999), something that is prevalent in the Nigerian market. To the extent that a greater confusion about the unique value of a new process and product may cause consumers to find it difficult to evaluate the true value in new process and product propositions (Walsh et al., 2007). As a result, the extent to which new process and product innovations drive market performance may be weakened as levels of consumer proneness to confusion increase. A related argument is that this result may reflect consumer inertia towards new products in dynamic markets where new processes and products are introduced rapidly. Even though consumers may desire new products to satisfy changing needs, they may become fatigued by the high rate of new process and product introductions, and could become reluctant to their adoption because they know new ones would be introduced in a short time period.

Second, one may argue that new process and product introduction may translate into stronger performance in markets that are stable rather than those that are constant flux. For example, in relatively stable markets such as the automobile industry, NPD capability (exhibited in introduction of new cars with fuel efficient engines or futuristic technologies like parking assists) directly increases a firm's competitive advantage. By contrast, in highly dynamic markets such as the smartphone market, greater NPD capability (e.g. in producing superior cameras and battery life for phones) may not guarantee stronger market performance because the value proposition may be wiped out by the many firms capable of rapidly replicating or introducing more advanced new phone features.

Consistent with the study's prediction, findings from this study show that the effect of NPD capability on market performance is stronger when levels of market responsiveness are greater. This suggests that, firms need greater market responsiveness ability to be able to channel their creativity resources, via NPDA capabilities, to market performance. In other words, an ability to understand and respond to target market needs and demands is a complementary organizational capability that enables firms to channel their creative activities, via NPD capabilities, to stronger market performance. Overall, this study extends the organizational creativity-performance research and contributes to the growing 
body of literature by offering a robust account of the paths through which firm creativity influences market performance and the prevailing boundary conditions of this relationship.

\subsection{Managerial Implications}

Channelling organizational creativity into NPD activities involves complex organizational strategic decision making processes. Findings from this study provide a number of important implications for managers charged with managing the complexity involved. First, results from this study support the view that novel and useful creativity activities are both vital in driving new product development capabilities. To this end, managers must understand that adding both novel and useful features to new NPD processes and products would help generate stronger market performance. This is because both dimensions of creativity contribute to customer satisfaction: the novelty aspect helps address consumers' desire for distinct and (in some cases) technologically advanced new products while the usefulness dimension is key since many consumers do not buy new products unless they find value provided by the product important. As a result, developing new processes and products with both novel and useful features is instrumental in achieving overall superior market performance.

Second, findings from the study highlight the need for caution in the extent to which NPD capabilities are deployed in dynamic environments. Contrary to previous research (e.g. Story et al., 2015) that suggests that firms benefit more from product innovativeness in highly dynamic environments, results of this study do not support such an assertion. Instead, findings indicate that environmental dynamism negatively moderates the effect of NPD capabilities on performance. The direct implication of this finding for NPD managers is that efforts should be expended to minimise the risk of decreasing performance outcomes by taking into account the peculiarities of target market conditions when deploying NPD capabilities. Additionally, given that greater responsiveness to local market needs strengthens firms' ability to deploy NPD capabilities effectively to boost performance, it is important that managers invest efforts in understanding changing needs and preferences in key targeted markets to be able to continuously and accurately respond to customer needs with appropriate new processes and products to boost performance. 


\section{LIMITATIONS AND DIRECTIONS FOR FUTURE RESEARCH}

As with any study, the results of this research must be evaluated in light of certain limitations. The first limitation is in relation to the sample frame used to test the study's propositions. The study selected SMEs in a developing market, meaning that larger firms and firms in developed countries that are also involved in channelling organizational creativity for superior market performance were excluded from the study. This limits the generalization of the study's findings to such firms. Future empirical investigation across both a range of developed and developing economy firms would help enrich scholarly understanding in this field and importantly contribute to the generalizability of findings. Additionally, it would be interesting to examine the relationships in the context of more matured firms operating in more advanced markets as this would offer a richer understanding of how NPD capabilities mediate the path from organizational creativity to market performance.

Second, this research focuses on one mediator and only two moderating factors. There is a need for further research to identify and explore additional intervening and contingency variables. For example, product differentiation and competitive advantage can be tested as mediating variables (Song \& Parry, 1997) while conditioning variables such as technological turbulence, organizational structure and heterogeneity can be tested to offer a more grounded and comprehensive explanation of creativity and its relationship with performance outcomes.

Third, although this study tested but found no evidence for a potential quadratic effect of organizational creativity on NPD capabilities and performance, future research should seriously consider testing for these effects further. This call is informed by the suggestion that creativity, and its consequences, is a complex and dynamic process (Sarooghi, Libaersa, \& Burkemper, 2015). Hence, evidence on the levels of organizational creativity that is sufficient for boosting NPD capability would help shed new light on how firms can manage their creativity resources for optimal outcomes. 


\section{References}

Agnihotri, R., Rapp, A. A., Andzulis, J. M., \& Gabler, C. B. (2014). Examining the drivers and performance implications of boundary spanner creativity. Journal of Service Research, 17(2), 164-181.

Aiken, L. S., West, S. G., \& Reno, R. R. (1991). Multiple regression: Testing and interpreting interactions. Sage.

Amabile, T. M. (1988). A model of creativity and innovation in organizations. Research in organizational behavior, 10(1), 123-167.

Audretsch, D. B., \& Belitski, M. (2013). The missing pillar: The creativity theory of knowledge spillover entrepreneurship. Small Business Economics, 41(4), 819-836.

Axtell, C. M., Holman, D. J., Unsworth, K. L., Wall, T. D., Waterson, P. E., \& Harrington, E. (2000). Shopfloor innovation: Facilitating the suggestion and implementation of ideas. Journal of occupational and organizational psychology, 73(3), 265-285.

Barney, J. (1991). Firm resources and sustained competitive advantage. Journal of management, 17(1), 99-120.

Bharadwaj, N., \& Dong, Y. (2014). Toward Further Understanding the Market- sensing CapabilityValue Creation Relationship. Journal of Product Innovation Management, 31(4), 799-813.

Calantone, R. J., Cavusgil, S. T., \& Zhao, Y. (2002). Learning orientation, firm innovation capability, and firm performance. Industrial marketing management, 31(6), 515-524.

Chan, H. K., Yee, R. W., Dai, J., \& Lim, M. K. (2016). The moderating effect of environmental dynamism on green product innovation and performance. International Journal of Production Economics, 181, 384-391.

Christensen, C. M. (2013). The innovator's dilemma: when new technologies cause great firms to fail. Harvard Business Review Press.

Christensen, C. 2000. The Innovator's Dilemma. New York: Harpers Business.

Csikszentmihalyi, M., \& Sawyer, K. (2014). Shifting the focus from individual to organizational creativity. In the Systems Model of Creativity (pp. 67-71). Springer Netherlands.

Damanpour, F., \& Aravind, D. (2012). Organizational structure and innovation revisited: From organic to ambidextrous structure. Handbook of organizational creativity, 483-513.

Dawson, J. F. (2014). Moderation in management research: What, why, when, and how. Journal of Business and Psychology, 29(1), 1-19.

Ermeç Sertoğlu, A., \& Kavak, B. (2017). A More Comprehensive View of Consumer Confusion: Scale Development. Journal of International Consumer Marketing, 1-12. 
Eryigit, N. \& Uslu, T. (2016). The effect of organizational creativity on team performance by mediating role of self-organization and team perception in SMEs, public and private sector. Eurasian journal of business and management. 4(2), 65-71.

George, C. (2002). Why Do Some Companies Thrive While Others Fail? Journal of organizational Behaviour. 12(8), 4-16.

Gibbert, M., Hoegl, M., \& Valikangas, L. (2014). Introduction to the special issue: Financial resource constraints and innovation. Journal of Product Innovation Management, 31(2), 197-201.

Glăveanu, V. P. (2014). Theorising context in psychology: The case of creativity. Theory \& Psychology, 24(3), 382-398.

Gong, Y., Zhou, J. \& Chang, S. (2013). Core Knowledge Employee Creativity and Firm Performance: The moderating role of riskiness orientation, firm size and realized absorptive capacity. Personnel Psychology, 66(2), 443-482.

Hannan, M. T., \& Freeman, J. (1993). Organizational ecology. Harvard University Press.

Hayes, A. F. (2013). Model templates for PROCESS for SPSS and SAS. Retrieved December, 12, 2013.

Hennessey, B.A. \& Amabile, T.M. (2010). Creativity. Annual Review of psychology. 61(1), 569-598.

Hogan, S. J., \& Coote, L. V. (2014). Organizational culture, innovation, and performance: A test of Schein's model. Journal of Business Research, 67(8), 1609-1621.

Hunt, S.D. \& Morgan, R.M. (1995). The Comparative Advantage Theory of Competition. Journal of Marketing, 59(4), 1-15.

Im, S. \& Workman, P.J. (2004). Market Orientation, Creativity and New product performance in high technology firms. Journal of Marketing, 68(2), 114-132

International Business Machines. (2010). 2010 IBM Global CEO Study. New York: IBM Corporation.

Joshi, A.W. \& Campbell, A.J. (2003). Effect of environmental dynamism on relational governance in manufacturer-supplier relationships: a contingency framework and an empirical test. Journal of the Academy of Marketing Science, 31(2), 176-188.

Litchfield, R. C., Ford, C. M., \& Gentry, R. J. (2015). Linking individual creativity to organizational innovation. The Journal of Creative Behavior, 49(4), 279-294.

McMullan, W. E., \& Kenworthy, T. P. (2015). Towards a Macro Theory of Entrepreneurial Creativity. In Creativity and Entrepreneurial Performance (pp. 155-163). Springer International Publishing.

Mitchell, V. W., \& Papavassiliou, V. (1999). Marketing causes and implications of consumer confusion. Journal of Product \& Brand Management, 8(4), 319-342. 
Montag, T., Maertz, C.P. \& Baer, M. (2012). A critical analysis of the workplace creativity criterion space. Journal of Management, 38(4), 1362-1386.

Narver, J.C., Slater, S.F. \& MacLachlan, D.L. (2004). Responsive and Proactive Market Orientation and New-Product Success. Journal of Product Innovation Management, 21(5), 334-347.

Nordenflycht, A.V. (2007). Is public ownership bad for professional service firms? Ad agency ownership, performance and creativity. Academy of Management Journal, 50 (2), 429-445.

Ofek, E., \&Wathieu, L. (2010). Are you ignoring trends that could shake up your business? Harvard Business Review, 88 (7/8), 124-131.

Oldham, G.R \& Cummings, A. (1996). Employee Creativity: personal and contextual factors at work. Academy of management journal, 39 (3), 607-634.

Rousseau, M. B., Mathias, B. D., Madden, L. T., \& Crook, T. R. (2016). Innovation, firm performance, and appropriation: A meta-analysis. International Journal of Innovation Management, 20 (03), 1650033.

Sethi, R., Smith, D.C. \& Park, C.W. (2001). Cross-functional Product Development Teams, Creativity and the Innovativeness of new consumer products. Journal of Marketing Research 38 (2), 73 85.

Sheth, J. N. (2011). Impact of emerging markets on marketing: Rethinking existing perspectives and practices. Journal of Marketing, 75 (4), 166-182.

Sirén, C. A., Kohtamäki, M., \& Kuckertz, A. (2012). Exploration and exploitation strategies, profit performance, and the mediating role of strategic learning: Escaping the exploitation trap. Strategic Entrepreneurship Journal,6 (1), 18-41.

Sok, P., \& O'Cass, A. (2015). Examining the new product innovation-performance relationship: Optimizing the role of individual-level creativity and attention-to-detail. Industrial Marketing Management, 47, 156-165.

Somech, A., \& Drach-Zahavy, A. (2013). Translating team creativity to innovation implementation: The role of team composition and climate for innovation. Journal of Management, 39 (3), 684708.

Song, X.M. \& Parry, M.E. (1997). A Cross-National Comparative Study of New Product Development Processes: Japan and the United States. Journal of Marketing, 61 (4), 1-18.

Story, V.M., Boso, N. \& Cadogan, J.W. (2015). The form of relationship between firm-level product innovativeness and new product performance in developed and emerging markets. Journal of Product Innovation Management, 32 (1), 45-64.

Trading Economics (2016). Nigerian Population 1960-2016. [Online]. [Accessed 15 ${ }^{\text {th }}$ July, 2016]. Available from: http://www.tradingeconomics.com/nigeria/population 
Troilo, G., De Luca, L. M., \& Atuahene- Gima, K. (2014). More innovation with less? A strategic contingency view of slack resources, information search, and radical innovation. Journal of Product Innovation Management, 31 (2), 259-277.

Walsh, G., Lindridge, A., Mitchell, V. W., Deseniss, A., \& Lippold, A. (2016). Investigating consumer confusion proneness cross-culturally: empirical evidence from the USA, Germany, and Thailand. International Journal of Markets and Business Systems, 2 (3), 226-242.

Walsh, G., Hennig-Thurau, T., \& Mitchell, V. W. (2007). Consumer confusion proneness: scale development, validation, and application. Journal of Marketing Management, 23 (7-8), 697721.

Wang, G. \& Maio, C.F. (2015). Effects of sales force market orientation on creativity, innovation implementation, and sales performance. Journal of Business Research, 68 (11), 2374-2382.

Wei, Y. S., Samiee, S., \& Lee, R. P. (2014). The influence of organic organizational cultures, market responsiveness, and product strategy on firm performance in an emerging market. Journal of the Academy of Marketing Science, 42 (1), 49-70.

Weinzimmer, L.G., Michel E.J., \& Franczak, J.L. (2011). Creativity and firm-level performance: the mediating effects of action orientation. Journal of Managerial Issues, 23(1), 62-82.

Wernerfelt, B. (1984). A Resource-Based View of the Firm. Strategic Management Journal, 5(2), 171-180.

Woodman, R.W, Sawyer, J.E \& Griffin, R.W. (1993). Towards a theory of Organizational Creativity. Academy of Management Review, 18(2), 293-321.

Woodward, S. E., \& Hall, R. E. (2012). Diagnosing consumer confusion and sub-optimal shopping effort: Theory and mortgage-market evidence. The American Economic Review, 102(7), 32493276

Zaltman, G., Duncan, R., \& Holbek, J. (1973). Innovations and organizations. John Wiley \& Sons.

Zeschky, M. B., Winterhalter, S., \& Gassmann, O. (2014). From cost to frugal and reverse innovation: Mapping the field and implications for global competitiveness. Research-Technology Management, 57 (4), 20-27.

Zhao, Z.J. \& Chadwick, C. (2013). What we will do versus what we can do: the relative effects of unit-level NPD motivation and capacity. Strategic Management Journal, 35 (12), 1867-1880. 
Figure 1: Conceptual Model

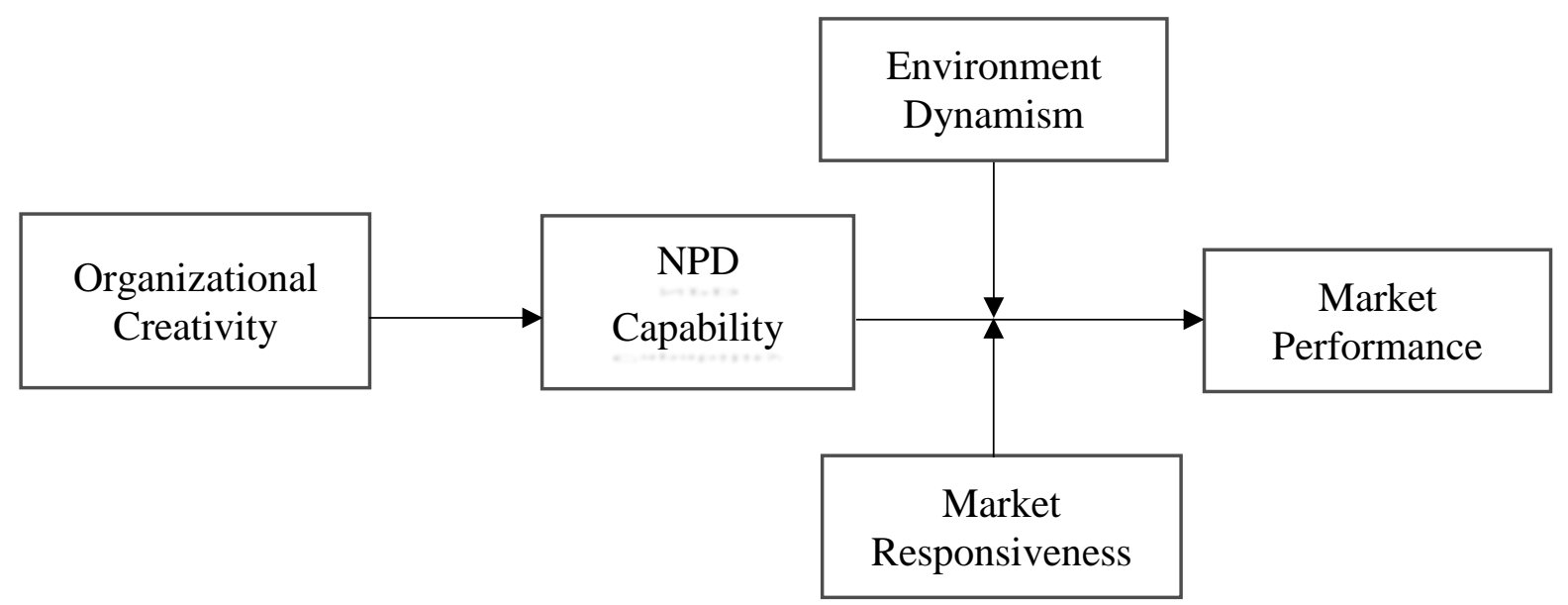


Figure 2a: Interaction Between Environment Dynamism and New Process Capability

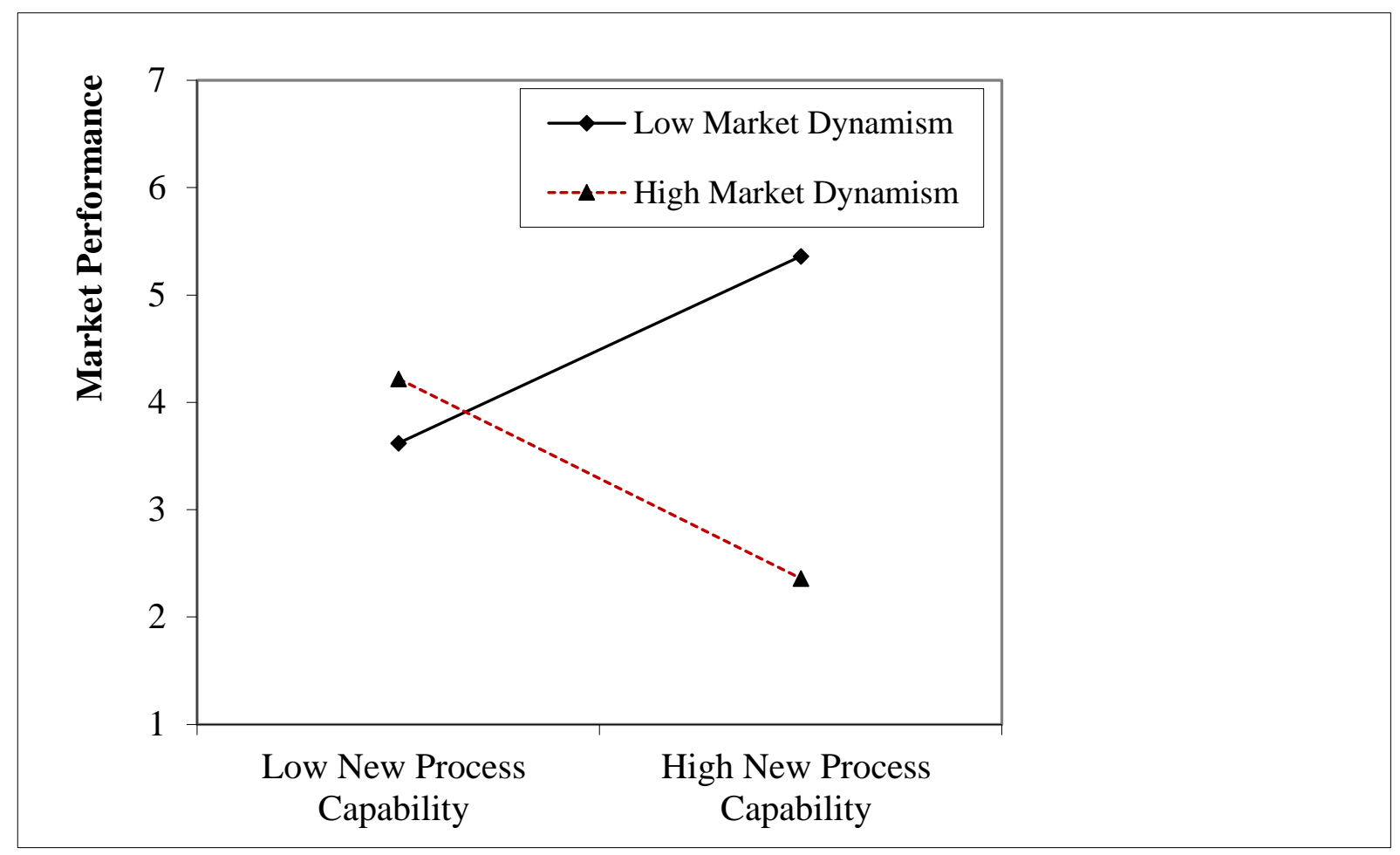


Figure 2b: Interaction Between Environment Dynamism and New Product Capability

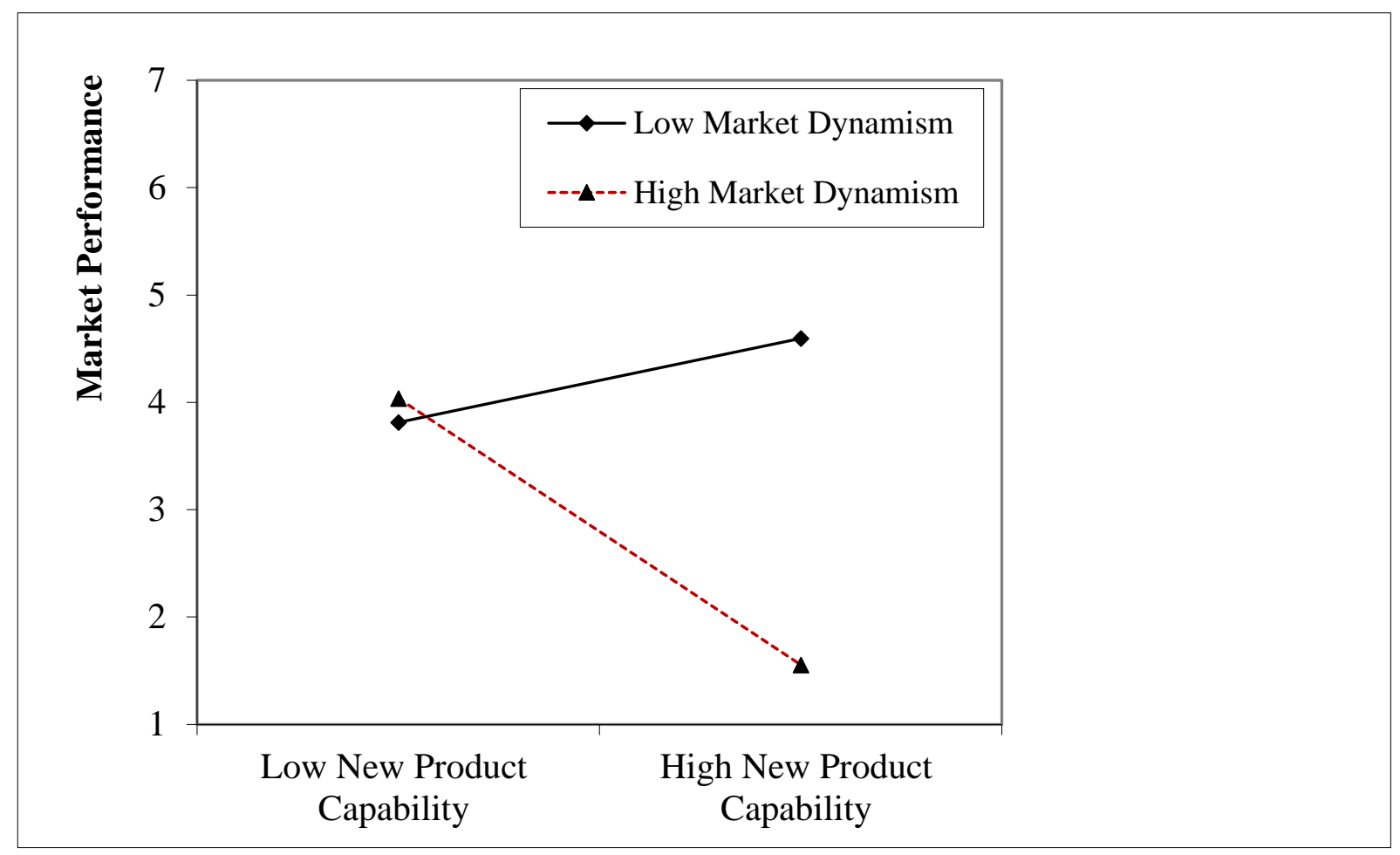


Figure 3a: Interaction Between Market Responsiveness and New Product Capability

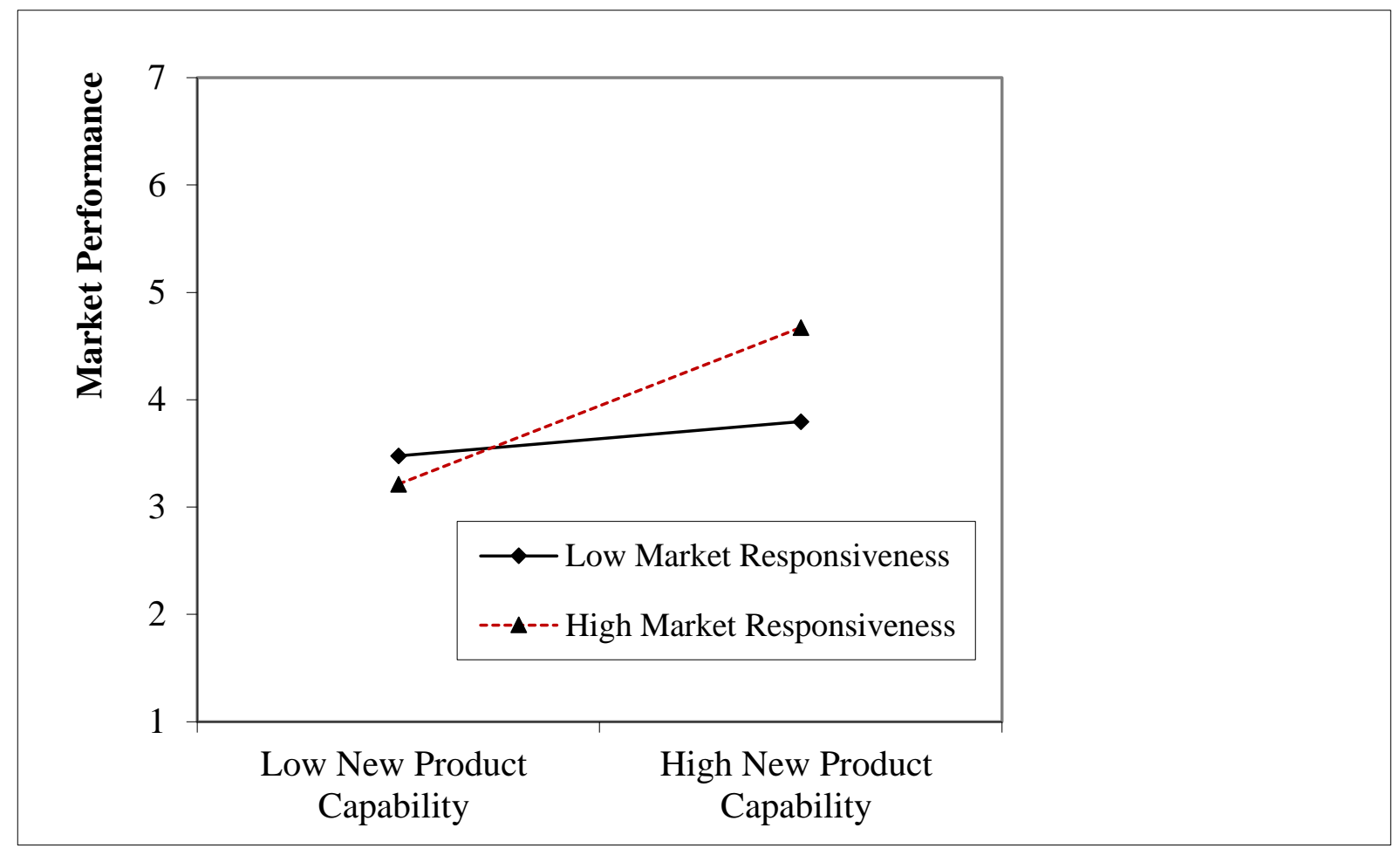


Figure 3b: Market Responsiveness and New Process Capability

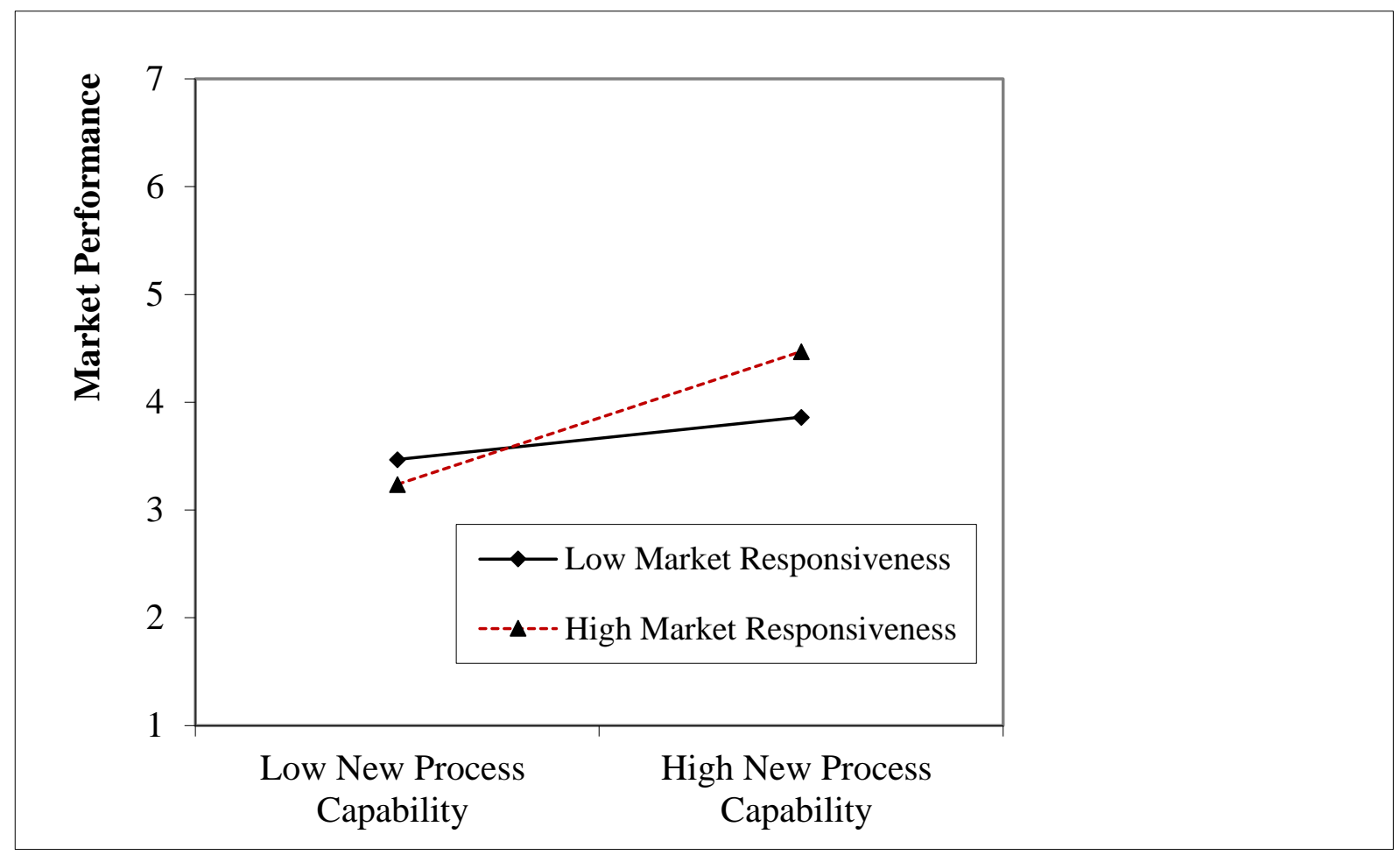




\begin{tabular}{|c|c|c|c|c|}
\hline Constructs and their measures & Alpha & $\mathbf{C R}$ & AVE & $\begin{array}{l}\text { Factor } \\
\text { Loading } \uparrow\end{array}$ \\
\hline \multicolumn{5}{|l|}{ Organizational Creativity (Sue-Chan \& Hempel, 2016) } \\
\hline Novelty & .863 & .906 & .658 & \\
\hline \multicolumn{5}{|l|}{ In our target market...: } \\
\hline -we normally have original ideas & & & & .806 \\
\hline -we often have fresh approaches to problems & & & & .857 \\
\hline -we have a unique perspective to solving problems & & & & .834 \\
\hline -we usually generate unprecedented solutions to problems & & & & .740 \\
\hline -our solution to problems is often different from traditional ways of solving problems & & & & .796 \\
\hline Usefulness & .901 & .881 & .661 & \\
\hline \multicolumn{5}{|l|}{ In our target market: } \\
\hline -we normally produce simple solutions to problems & & & & .721 \\
\hline -we focus on identifying adequate plans for the implementation of our new ideas & & & & .878 \\
\hline -we often integrate multiple perspectives constructively & & & & .791 \\
\hline -we usually combine ideas in a constructive manner & & & & .714 \\
\hline \multicolumn{5}{|l|}{ NPD Capability (Adapted from Atuahene-Gima \& Li, 2004; Calantone et al. 2002) } \\
\hline NPD Capability - Process & .926 & .930 & .768 & \\
\hline $\begin{array}{l}\text {-We update our business processes (e.g. technical, administrative, production, channels of distribution) more } \\
\text { often than our main competitors }\end{array}$ & & & & .830 \\
\hline $\begin{array}{l}\text {-We innovate more often with respect to our business processes (e.g. technical, administrative, production, } \\
\text { channels of distribution) than our key target market competitors }\end{array}$ & & & & .858 \\
\hline $\begin{array}{l}\text {-The rate at which we innovate our business processes (e.g. technical, administrative, production, channels of } \\
\text { distribution) exceeds industry norms }\end{array}$ & & & & .785 \\
\hline $\begin{array}{l}\text {-Competitors undertake business process innovations (e.g. technical, administrative, production, channels of } \\
\text { distribution) less often than we do }\end{array}$ & & & & .774 \\
\hline NPD Capability - Product & .919 & .898 & .688 & \\
\hline $\begin{array}{l}\text {-Our company has produced more new products/services for our target markets than our key target market } \\
\text { competitors during the past five years }\end{array}$ & & & & .867 \\
\hline $\begin{array}{l}\text {-On average, each year we introduce more new products /services in our target markets than our key target } \\
\text { market competitors }\end{array}$ & & & & .876 \\
\hline $\begin{array}{l}\text {-Industry experts would say that we are more prolific when it comes to introducing new products/services in } \\
\text { our target markets }\end{array}$ & & & & .888 \\
\hline $\begin{array}{l}\text {-Our key target market competitors cannot keep up with the rate at which we introduce new products/services } \\
\text { in our target markets }\end{array}$ & & & & .814 \\
\hline
\end{tabular}




\begin{tabular}{|c|c|c|c|c|}
\hline Constructs and their measures & Alpha & CR & AVE & $\begin{array}{l}\text { Factor } \\
\text { Loading } \uparrow\end{array}$ \\
\hline Environmental Dynamism (Jaworski \& Kohli, 1993) & .822 & .908 & .610 & \\
\hline -In our target market environments new markets are emerging for products and services & & & & 706 \\
\hline -In our target market environments there are lots of new competitors & & & & .761 \\
\hline -In our target market environments competitors are constantly trying out new competitive strategies & & & & .815 \\
\hline -In our target market environments customer needs and demands are changing rapidly & & & & .823 \\
\hline In our target market environments production/manufacturing technology is constantly changing & & & & .750 \\
\hline Market Responsiveness (Jaworski \& Kohli, 1993) & .791 & .832 & .557 & \\
\hline -we are quick to respond to important changes in our local market environment (e.g., regulation, technology) & & & & .651 \\
\hline $\begin{array}{l}\text {-we are quick to respond to significant changes in our local market competitors' price structures in target } \\
\text { markets }\end{array}$ & & & & .728 \\
\hline -we rapidly respond to local market competitive actions that threaten us in our target markets & & & & .842 \\
\hline $\begin{array}{l}\text {-if a major local market competitor were to launch an intensive campaign targeted at our customers, we would } \\
\text { implement a response immediately }\end{array}$ & & & & .594 \\
\hline Market Performance (Siren et al., 2012) & .882 & .912 & .724 & \\
\hline -sales revenue & & & & .870 \\
\hline -market share & & & & .981 \\
\hline -sales growth & & & & .841 \\
\hline -market share growth & & & & .677 \\
\hline \multicolumn{5}{|l|}{ Fit Statistics } \\
\hline Chi-square $(\chi)$ & \multicolumn{2}{|c|}{ SRMR } & & \\
\hline 682.321 & \multicolumn{2}{|c|}{.049} & & \\
\hline
\end{tabular}

Note: $\mathrm{CR}=$ composite reliability; $\alpha=$ Cronbach's Alpha; AVE = Average Variance Extracted; DF = Degree of Freedom; RMSEA = Root Mean Square Error of Approximation; NNFI = None-normed

Fit Index; CFI = Comparative Fit Index; SRMR = Standardized Root Mean Square Residual; $\uparrow=$ standardized estimates are reported 
Table 2: Descriptive Statistics and Inter-Construct Correlation

\begin{tabular}{|c|c|c|c|c|c|c|c|c|c|c|c|c|c|}
\hline & & Mean & SD & 1 & 2 & 3 & 4 & 5 & 6 & 7 & 8 & 9 & 10 \\
\hline 1 & Market performance & 4.788 & 1.185 & 1.000 & & & & & & & & & \\
\hline 2 & NPD capability- Process & 4.472 & 1.083 & .221 & 1.000 & & & & & & & & \\
\hline 3 & NPD capability - Product & 4.261 & 1.311 & .148 & .717 & 1.000 & & & & & & & \\
\hline 4 & Creativity - Novelty & 4.622 & 1.008 & .220 & .368 & .262 & 1.000 & & & & & & \\
\hline 5 & Creativity - Usefulness & 4.883 & 1.179 & .138 & .328 & .249 & .495 & 1.000 & & & & & \\
\hline 6 & Market responsiveness & 5.144 & 1.095 & .221 & .289 & .191 & .246 & .180 & 1.000 & & & & \\
\hline 7 & Environment dynamism & 4.110 & 1.270 & .137 & .061 & .070 & -.054 & .010 & .155 & 1.000 & & & \\
\hline 8 & Industry dummy & - & - & .034 & .008 & .052 & -.051 & -.039 & .011 & .017 & 1.000 & & \\
\hline 9 & Firm experience (Years) & 51.403 & 37.817 & -.064 & -.021 & .025 & -.092 & .018 & .077 & -.103 & .049 & 1.000 & \\
\hline 10 & Firm size (Employees) & 83.814 & 60.357 & -.138 & -.064 & -.003 & -.110 & .002 & -.112 & .066 & -.097 & .015 & 1.000 \\
\hline
\end{tabular}


Table 3: Results of Structural Equation Modelling

\begin{tabular}{|c|c|c|c|c|c|}
\hline & \multicolumn{2}{|c|}{ NPD Capabilities } & \multicolumn{3}{|c|}{ Market Performance } \\
\hline & NPD Product & NPD Process & Model 1 & Model 2 & Model 3 \\
\hline $\begin{array}{l}\text { Control Paths } \\
\text { Industry } \\
\text { Business experience } \\
\text { Firm size } \\
\text { Main Effect Paths } \\
\text { Creativity novelty } \\
\text { Creativity usefulness } \\
\text { NPD process capability } \\
\text { NPD product capability } \\
\text { Dynamism } \\
\text { Responsiveness } \\
\text { Interaction Effect Paths } \\
\text { NPD process x Dynamism } \\
\text { NPD product x Dynamism } \\
\text { NPD process x Responsiveness } \\
\text { NPD product x Responsiveness }\end{array}$ & $\begin{array}{l}-.024(-.295) \\
.071(.599) \\
-.157(-1.563) \\
.278\left(3.332^{* *}\right) \\
.289\left(4.774^{* *}\right) \\
- \\
-\end{array}$ & $\begin{array}{l}-.032(-.398) \\
.072(.607) \\
-.159(-1.607) \\
.302\left(5.136^{* *}\right) \\
.611\left(10.225^{* *}\right) \\
- \\
-\end{array}$ & $\begin{array}{l}-.037(-.453) \\
.069(.579) \\
-.154(-1.547) \\
.187\left(1.840^{\dagger}\right) \\
.061(.832) \\
.171(1.972 *) \\
.202(2.432 * *) \\
- \\
-\end{array}$ & $\begin{array}{l}-.042(-.516) \\
.072(.612) \\
-.149(-1.503) \\
.181\left(1.804^{\dagger}\right) \\
.042(.570) \\
.172(1.983 *) \\
.160(1.960 *) \\
-.158(-.733) \\
.127(1.599)\end{array}$ & $\begin{array}{l}-.036(-.440) \\
.078(.653) \\
-.143(-1.425) \\
.198\left(1.914^{\dagger}\right) \\
.043(.599) \\
.176\left(1.985^{*}\right) \\
.164\left(1.961^{*}\right) \\
-.056(-.199) \\
-.062(-.218) \\
-.188\left(-2.242^{* *}\right) \\
-.203\left(-3.221^{*} *\right) \\
.142(1.681 \dagger) \\
.192(1.962 *)\end{array}$ \\
\hline Goodness of Fit Indicators & & & & & \\
\hline $\begin{array}{l}\mathrm{R}^{2} \\
\text { Chi-square (DF) } \\
\text { RMSEA } \\
\text { NNFI } \\
\text { CFI } \\
\text { SRMR }\end{array}$ & .402 & $\begin{array}{l}.343 \\
0(50) \\
62 \\
78 \\
96 \\
39 \\
\end{array}$ & $\begin{array}{l}.281 \\
186.265(56) \\
.069 \\
.936 \\
.986 \\
.056\end{array}$ & $\begin{array}{l}.283 \\
178.433(54) \\
.031 \\
.957 \\
.983 \\
.048\end{array}$ & $\begin{array}{l}.286 \\
166.997(50) \\
.030 \\
.967 \\
.988 \\
.046\end{array}$ \\
\hline
\end{tabular}

Note: standardized coefficients are reported; $\mathrm{t}$-value; $\dagger \mathrm{p}<.10 ; * \mathrm{p}<.05 ; * * \mathrm{p}<.01$. Critical $\mathrm{t}$-values are respectively $1.645,1.960$, and $2.326(2$ tailed test) 